韓国住宅の敷地内空地の認識に関する研究

\title{
- A STUDY ON THE COGNITION OF THE OPEN SPACE WITHIN A SOUTH KOREAN RESIDENCE
}

\author{
金 奉 暻*1, 鈴木 毅*2, 小浦久子*3，木多道宏*2，李 斌*4，舟橋國 男*5 \\ Bongkyung KIM, Takeshi SUZUKI, Hisako KOURA, \\ Michihiro KITA, Bin LI and Kunio FUNAHASHI
}

\begin{abstract}
This research aims to clarify the definition of the open space, such as Madang and Garden within a South Korean residence. A survey consisting of 1195 South Korean subjects was conducted to analyze the physical, functional, emotional aspects of an open space. The survey suggested the definition of Madang and Garden slightly differed depending on the age group and the housing type of the subjects. 1) The older age groups, over 50 years old, had a tendency to acknowledged Madang as an essential feature of a South Korean residence, while perceiving the presence of a garden as unnecessary. 2) The definitions given by the subjects of a Madang illustrate strong traditional implications as well as their familiarity to the idea. The definition of a Garden insinuated an imagery of being green, beautiful, and classy. 3) A Madang was defined as a space for activities of a daily life, whereas Garden was defined as a space for rest and other activities involving greenery.

The broad definitions of open space given by the different age groups in this survey proposed the possibility of changing roles and/or configurations of an open space at a South Korean residence in future residential projects.
\end{abstract}

Keywords : Madang, Garden, Open space, Cognition マダン、庭（庭園）、敷地内空地、認識

\section{1. 研究の背景と目的}

韓国の住宅は、1980 年代からの急激な都市化により住宅の量的供給 中心の政策が余儀なくなされてきたが、1990 年代に入ってからはライフス タイルの変化に伴い、生活環境の質を高める方向へ進んでいる。その例 として、街路環境の整備、町づくり運動、塀崩し運動などへの市民参加の 動きなどが挙げられる。特に、1995 年から私有地を囲んでいる塀を崩し、 一般市民に公開する(塀崩し運動 ${ }^{11}$ 」が、行政施設、公共施設、商業施 設のみならず、一般住宅へも広がり、活発に行われている。しかし、韓国 住宅にふさわしい敷地内空地についての十分な論議が行われていない まま、「塀崩し」が行われ、西洋的な風景が形成され、韓国的な町並みが 崩れる可能性も無視できないと考えられる。さらに、塀崩し前後の変化の 調査 ${ }^{1} に よ る と 、$ 既存の敖地内空地の物理的な面での変化のみならず、

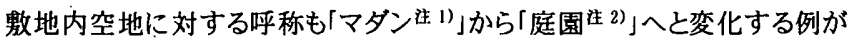
見られた。

韓国語辞書 ${ }^{2)}$ では、「マダン」は‘家の周りの平たく均一な空き地’、そし て、「庭」は‘トル (뜰)’と書かれており、「トル(들)」を調べると、“家の 中にある平たい地、「マダン」の古語’と書かれている。空間の呼称が変 化するということは、空間の役割や性格などの空間の定義が異なることを 示していると考えられるが、辞書における「マダン」庭」の語彙的な差異は 明確ではない。このような背景から、本研究では韓国住宅の中にある敷 地内空地一「マダン」庭」ーの役割や機能を明確にするために、その空
間を意味づける内容を認識の観点から分析することを目的とする。

韓国住宅の敷地内空地あるいは屋外空間に関する既存の研究として は、集合住宅の屋外生活空間についての意識および行為研究 ${ }^{31}$ 、韓 国固有の敷地内空地である「マダン」語意之特性についての研究 4)、そ して、「マダン」の機能と形態の変化に関しての調查研究 5)がある。また、李 ${ }^{6)}$ は、植民地時代の日本人向けの住宅である日式住宅を対象に、韓国 住文化の持続と変容を考察し、「マダン」本来の機能の他室への移転、 「マダン」のチョンウオン([庭園小、庭」)化を指摘している。また、全”は将来 の韓国住宅の敷地内空地のあり方として、既存の「マダン」が日常生活に 活用される役割を残しながらも、緑豊かな[庭園」的空間に変化する可能性 について語っている。しかし、韓国の現代住宅に実存する敷地内空地に ついて韓国人がどのように思い、空地の中ではどのような生活行為が行わ れているかを敷地内空地の種類別に調べた研究は未だに十分とは言え ない。

本研究は、これらの視点に基づき、韓国人を調查対象しして、韓国の現 代住宅の敷地内空地の「マダン」庭」などについて、韓国人の認識の中 の敖地内空地の物理的な面社 3)、敷地内空地から感じられるイメージ的な 面、敷地内空地における生活行為の面から調査を行い、考察する。

\section{2. 調查の概要}

本研究では、韓国人を対象に、韓国住宅の1階平面にある敷地内空

\footnotetext{
1 大阪大学大学院工学研究科建築工学専攻 博士後期課程・修士 (工学)

2 大阪大学大学院工学研究科建築工学専攻 助教授. 博士 (工学)

3 大阪大学大学院工学研究科地球総合工学尃攻 助教授 ·博士 (工学)

*4 大阪大学大学院工学研究科建築工学尃攻 助手・博士(工学)

*5 大阪大学 名誉教授 ·博士 (工学)
}

Graduate Student, Department of Architectural Engineering, Graduate School of Engineering, Osaka University, M. Eng. Assoc. Prof., Dept. of Architectural Engineering, Graduate School of Engineering, Osaka University, Dr. Eng.

Assoc. Prof., Dept. of Global Architectural Engineering, Graduate School of Engineering, Osaka University, Dr. Eng.

Research Assoc. Prof., Dept. of Architectural Engineering, Graduate School of Engineering, Osaka University, Dr. Eng. Emeritus Prof., Osaka University, Dr. Eng. 


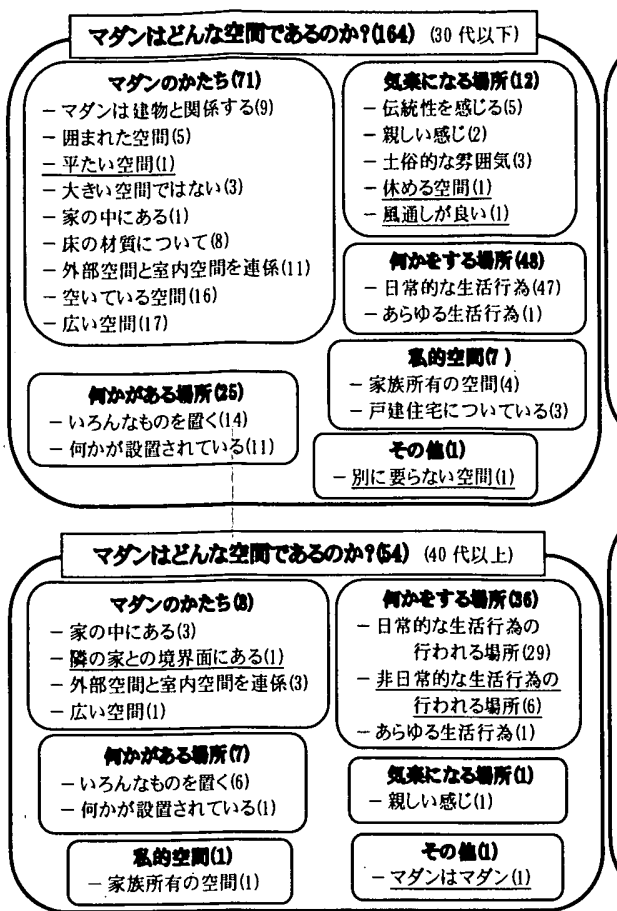

A. マダンの定義の模式図

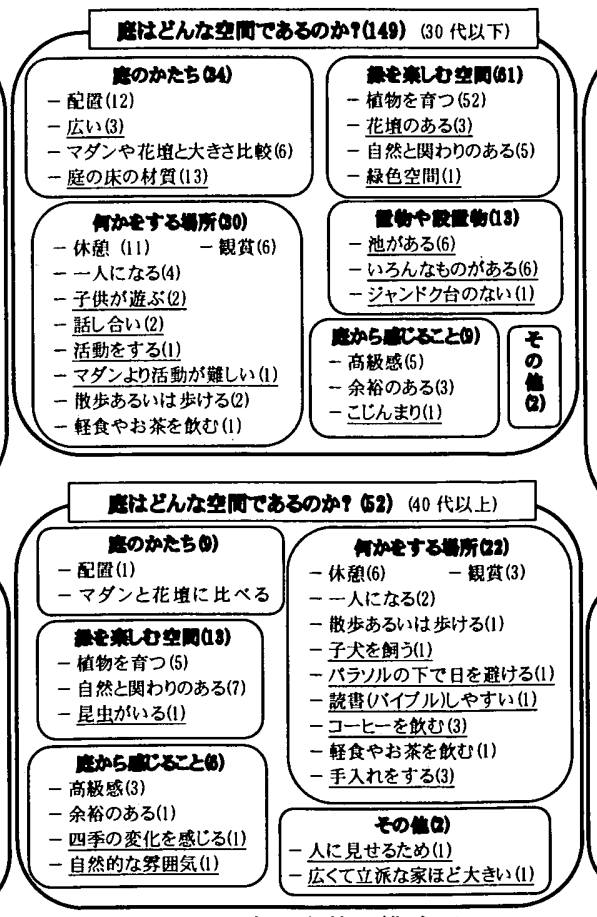

B. 庭の定義の模式図

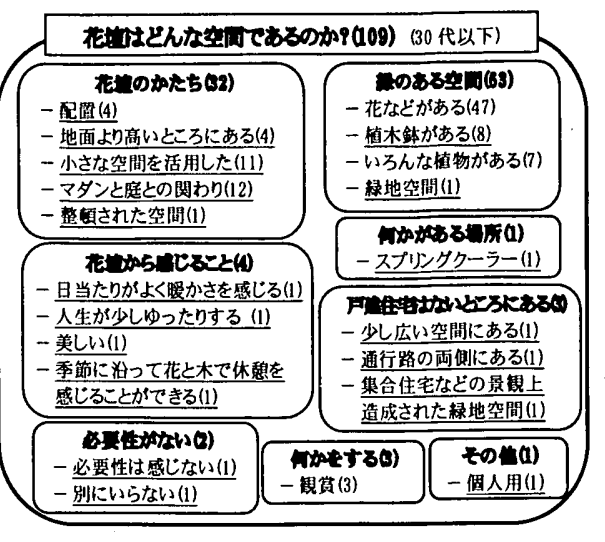

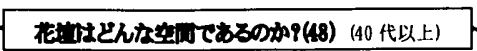

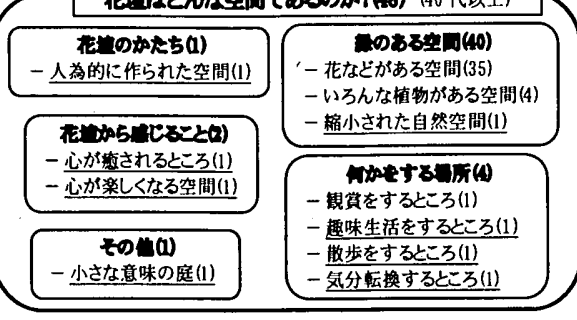

C. 花壇の定義の模式図

図-1敷地内空地に対する定義の模式図一年代別に区分 (下線の部分は該当年代別だけの意見)

表一 1 . 予備調査の調査対象者

\begin{tabular}{|c|c|c|c|c|c|c|c|}
\hline & 10 代以下 & 20 代 & 30 代 & 40 代 & 50 代 & 60 代以上 & 合計 \\
\hline 男性 & 8 & 24 & 26 & 3 & 0 & 13 & 74 \\
\hline 女性 & 1 & 7 & 4 & 4 & 6 & 15 & 37 \\
\hline 合計 & 9 & 31 & 30 & 7 & 6 & 28 & 111 \\
\hline
\end{tabular}

表-2. 本調査のアンケート項目

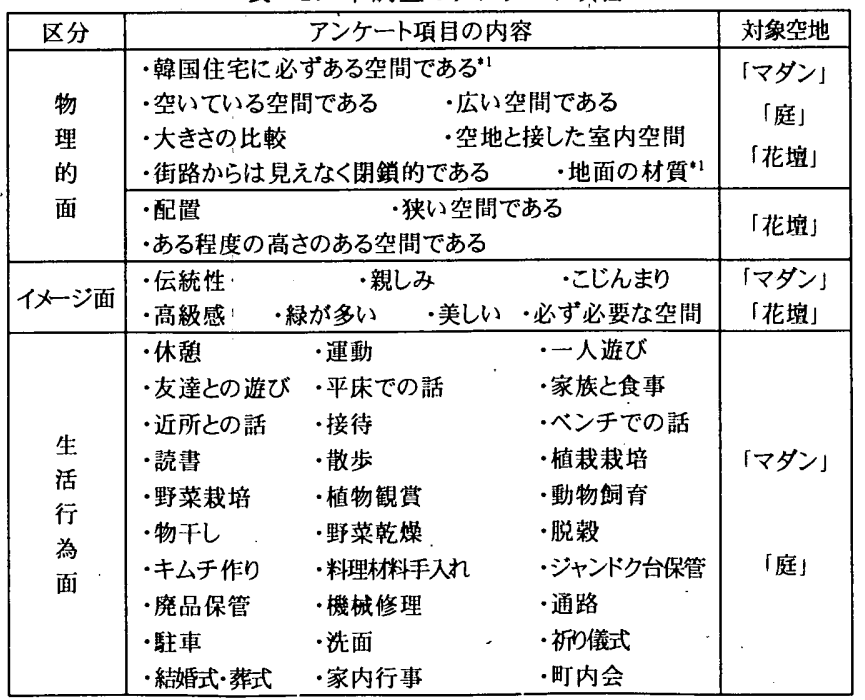

*1「花境」について設問した項目

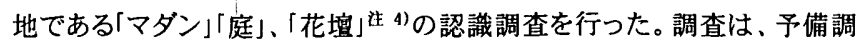
查と本調査で構成され、予備調查を 2003 年 10 月に、本調査を 2004 年 3 月に行った。

予備調查では韓国人 111 名(表ー1)を対象に「マダン」「庭」、花壇」の 三つの単語と空欄のあるシートを渡し、これらの敷地内空地について説 明してもらった。調查対象者に書いてもらった敷地内空地の説明文章に は様々な内容が入っているため、KJ 法 ${ }^{8)}$ を用いて、調查対象者の説明文 を分類し考察した。その結果、「マダン」「庭」、「花壇」に対する説明を 30
表-3. 物理的空間構造、イメージに関する考察対象者の 現在の住宅形式と年齢の関係

\begin{tabular}{|c|r|r|r|r|r|r|r|}
\hline 区分 & 10 代 & 20 代 & 30 代 & 40 代 & 50 代 & 60 代以上 & 計 \\
\hline 韓屋 & 13 & 8 & 13 & 3 & 4 & 2 & 43 \\
\hline 洋屋 & 113 & 65 & 47 & 15 & 10 & 10 & 260 \\
\hline 多世帯 & 84 & 48 & 48 & 14 & 7 & & 201 \\
\hline アパート & 231 & 130 & 168 & 82 & 24 & 4 & 639 \\
\hline その他 & 15 & 11 & 4 & 1 & 2 & 4 & 37 \\
\hline 計 & 456 & 262 & 280 & 115 & 47 & 20 & 1180 \\
\hline
\end{tabular}

無回答 15 名

表-4. 生活行為に関する考察対象者の現在の住宅形式と年齢の関倸

\begin{tabular}{|c|c|c|c|c|c|c|c|c|}
\hline & & 10 代 & 20 代 & 30 代 & 40 代 & 50 代 & 60 代以上 & 計 \\
\hline \multirow{6}{*}{$\begin{array}{l}\nabla \\
\text { タ } \\
\text { V }\end{array}$} & 韓屋 & 9 & 8 & 10 & 3 & 4 & 2 & 36 \\
\hline & 洋屋 & 56 & 43 & 35 & 9 & 6 & 9 & 158 \\
\hline & 多世帯 & 24 & 9 & 7 & 6 & 2 & & 48 \\
\hline & アパート & 11 & 11 & 22 & 13 & 4 & 1 & 62 \\
\hline & その他 & 3 & & 3 & & & 4 & 10 \\
\hline & 計 & -103 & 71 & 77 & 31 & 16 & 16 & 314 \\
\hline \multirow{6}{*}{ 庭 } & 韓屋 & 4 & 4 & 4 & 2 & 3 & 2 & 19 \\
\hline & 洋屋 & 15 & 13 & 16 & 4 & 2 & 4 & 54 \\
\hline & 多世带 & 12 & 2 & 5 & 3 & 2 & & 24 \\
\hline & アパート & 4 & 10 & 14 & 9 & 4 & 1 & 42 \\
\hline & その他 & 2 & 3 & 2 & & & 1 & 8 \\
\hline & 計 & 37 & 32 & 41 & 18 & 11 & 8 & 147 \\
\hline
\end{tabular}

「マダン」のある住宅；無回答 6 名、「庭」のある住宅；無回答 1 名

代以下及び 40 代以上に分け整理し、図-1 が得られた。

予備調查で得られた図-1の内容から、「マダン」庭にについて、共通項 目である空地の物理的な面、イメージ的な面、生活行為の面の項目を、 「花壇」については物理的な面の 5 つの項目を、さらに実際の韓国住宅の 敷地内空地の写真 ${ }^{\text {注 }}{ }^{5)} 9$ 枚を用意し、写真の中の敷地内空地がどのよう な呼称で呼ばれるかを調べるための項目を入れ、本調査のアンケート調 查表を作成した(表-2)。

アンケート調查表は韓国のプサン市とマサン市などの高校、大学校、 区役所、教会、一般会社へ合計 1,906 部を配布し、1,195 部を回収（回収 率; $62.7 \%$ した。分析において敷地内空地の物理的な面、イメージ的な面 
では回答者 1,195 名を対象者に、かつ敷地内空地での生活行為の面で は昔あるいは今に「マダン」「庭」での経験がある人注 6)一以前の住まいに 「マダン」のあった人 923 名、今の住まいに「マダン」のある人 320 名、以前 の住まいに「庭」のあった人 577 名、今の住まいに「庭」のある人 148 名-を 対象にして行った。さらに、予備調查で年㱓別に敷地内空地に対して異 なるイメージを持っていたことが特徵的であった点から、本調査でも調査 対象者を年齢別に区分し考察を行う。さらに対象者の今の住まいの種類 別(住宅形式別)にその属性を分類し考察する。その概要については表 $-3 、$ 表 -4 に示す。

\section{3.數地内空地の物理的な特性}

この章は、表一2.ににおける数地内空地の物理的な側面に関する考察 である。 5 つの項目について得られた結果を、年踰別と現在の住宅形式

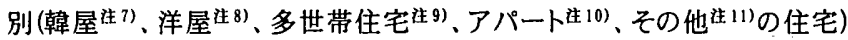
に分けて図-2 と図-3 に示す。

\section{1 韓国住宅の中での存在性}

韓国住宅に、当該敷地内空地が実際にあるかどうかを調べるため、「マ ダン」庭」「花壇」において「韓国住宅に必ずある空間である」という項目 について尋ねた。「ダン」においてはおよそ $50 \%$ (「分からない」「無回 答」の答えを除くと $56 \%)$ 人が、そして、「庭」は 244 名 $20.4 \%$ 、「分から ない「「無回答」の答えを除くと25\%)、「花壇」は 283 名(23.6\%、「分からな い「無回答」の答えを除くと $32 \%)$ が「韓国住宅に必ずある」回答した。

年齢別に見ると、20 代以上の過半数(特に 60 代以上においては $75 \%$ 以上の回答者)が、「マダン」の存在性について「そうである」認識してい るが、10 代以下の若い世代は「そうではない」と認識している回答者が多 かった(図-2 の上)。「庭」や「花壇」については、年秢区分を問わずほとん ど「そうではない」評価した回答者が多かった。

そして、住宅形式別に見ると、「マダン」については韓屋、洋屋、アパー 卜住まいの過半数の人が「そうであると、庭」と花壇」については住宅形 式別の区分を問わず「そうではない」認識していた(図-2の下)。

高年秢であるほど、また韓屋・洋屋に現在住んでいる人ほど、多くの回 答者が「マダン」での経験があると考えられ、敷地内空地の存在性は当該 空地での経験と関係があると考えられる。

\section{2 敷地内空地のかたち}

敷地内空地の大きさについて、予備調査では「マダン」〉「庭」〉[花壇」 であるとの結果を得たが、さらに詳しく調查するため、本調查においても 敷地内空地の大きさを尋ねた。単純集計で得られた結果を見ると、432

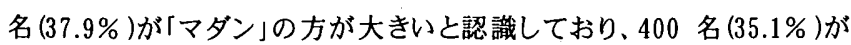
「庭」の方が大きいと認識しており、「マダン」と「庭」の間には明確な差がな いことが分かった(図-3(A)の左)。年齢別に見ると、40 代、50 代、60 代以 上の高齢者層の多くが「マダン」の方が「庭」より大きいと回答し、10 代以 下、20 代の多くが庭」の方が大きいと認識している。また、一戸建て住宅 である韓屋と洋屋を比較すると、韓屋住まいの人は「マダン」〉「庭」と回 答した人が多く、洋屋住まいの人は「庭」〉ママダン」と回答した人が多か った(図-3(A)の右)。伝統的な住宅形式である韓屋住まいの人と高跉者 層の人が庭」より「マダン」が大きいと認識していることが分かった。

また、「空いている空間」という項目については、年榆、住宅形式を問わ

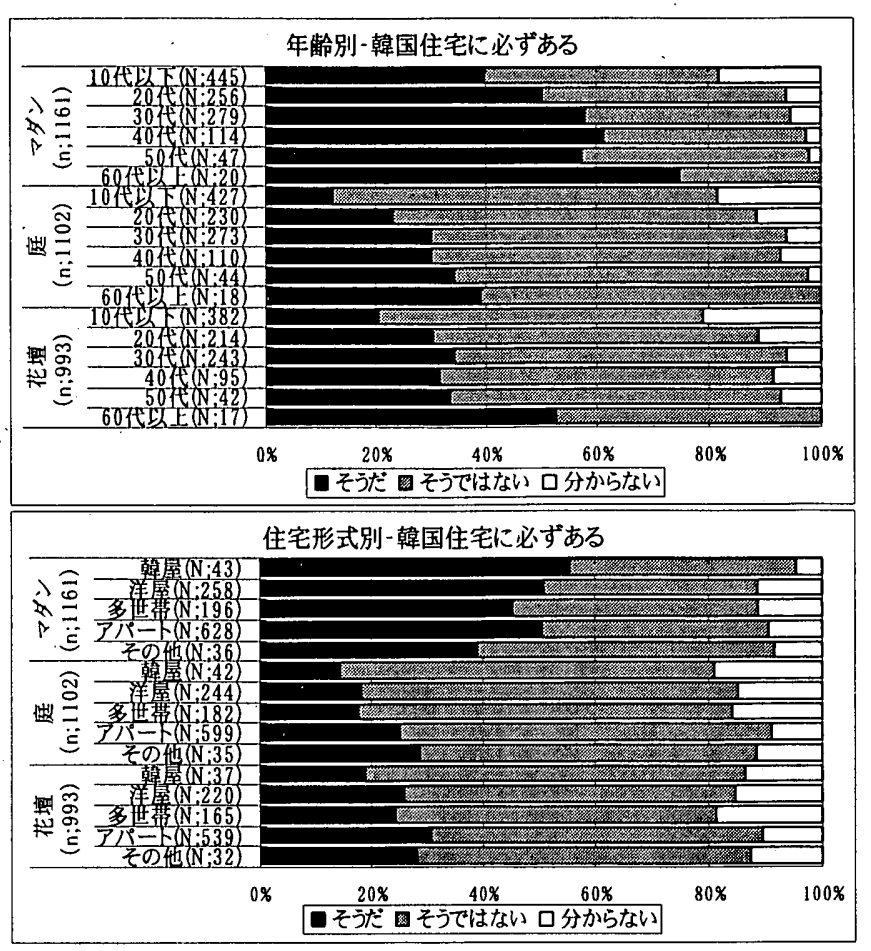

図ー2．「韓国住宅に必ずあるの設問に対する認識

(A)

(B)

(C)

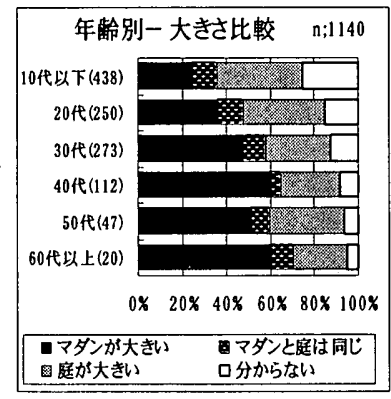

住宅形式別一大きさ比較 $n ; 1140$

$$
\text { 新(43) }
$$

洋屋 (253)

多世帶(189)

アバート(619)

その他(36)

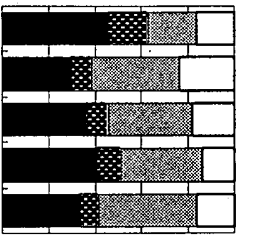

0\% $20 \% \quad 40 \% \quad 60 \% \quad 80 \% \quad 100 \%$

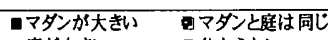
回庭か大きい 分からない

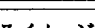

敷地内空地に対するイメージ

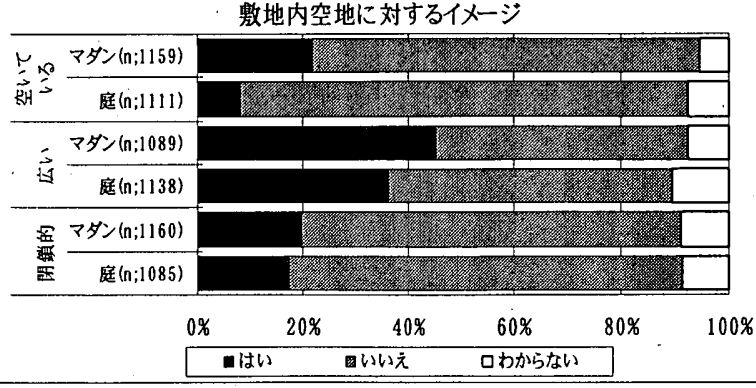

敷地内空地の床の材質
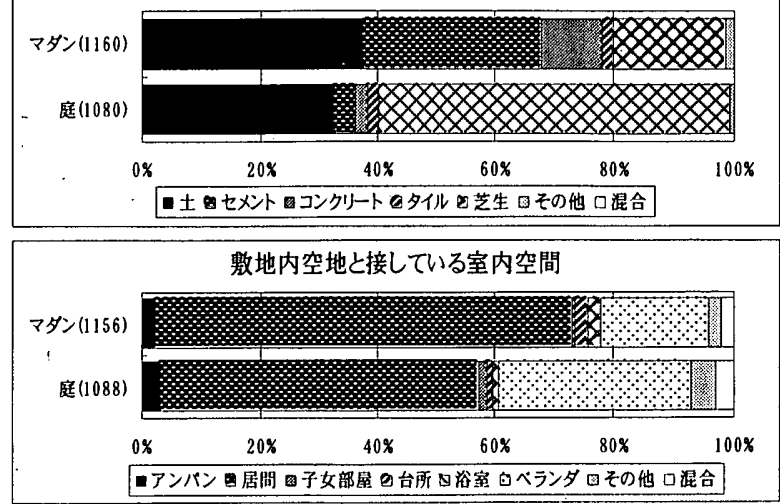

図－3．敖地内空地の姿に対するイメージ 
ずほとんどの回答者が「マダン」庭」とも「空いていない」と回答し、日常的 な活動のため品物や設備が置かれているためであると考えられる(図-3 のB)。しかし、60 代以上の回答者は「タタン」庭」とも空いていると認識し ているのが特徵的であった。これは敷地内空地で日常的な作業場、非日 常的には結婚式·葬式などの家内行事、あるいは近隣行事などが行われ たこと、すなわち、使うために空けておく経験のある人が高く評価した原 因ではないかと考えられる。

次に、「敷地内空地は広い」の項目では、「マダン」については 40 代お よび 60 代以上の過半数が広いと回答したが、その他の年踰では明確な 特徵が見出されなかった。また、住宅形式別においても同様であった (図-3のB)。「庭」については年齢、住宅形式を問わず、大抵の人が広くな いと回答したが、10 代以下の人の方が若干「庭」が広いと認識していた。

「敷地内空地は閒鎖的である」の項目では、「マダン」「庭」とも $65 \%$ 以上 の回答者が閉鎖的ではないと回答していた(図-3のB)。

「地面の材質にについての項目では、「マダン」は土(全体 401 名 35.1\%)、 セメント(328名、28.7\%)の順となったが、10 代以下、60 代以上、および現 在洋屋住まいの人はセメンと回答する人が多かった。「庭」は年齢、住宅 形式を問わず芝生(590 名 55.0\%)、土(327 名、30.5\%)の順となっていた (図-3のC)。そして、「花壇」は年龄、住宅形式を問わず、全体の 804 名 (72.6\%)の回答者が土と回答した。

「マダン」「庭」と「接する室内空間」としては、年齢・住宅形式を問わず、過 半数が居間(韓国語ではゴシル、フ실) と回答した。(図-3のD)

以上より、「マダン」「庭」の認識上の物理的な面では、年龄別・住宅形 式によって認識のしかたが異なることが分かった。高年龄であるほど、ま た現在韓屋住まいの人であるほど、「マダン」の存在性に対する認識が高 く、「マダン」は「庭」より大きく、空いていて、広く、閒鎖的ではない空間と して認識されている。しかし、年齢が若くなるほど、また、現在洋屋住まい の人であるほど庭」は「マダン」より大きくなるなど、同じ韓国人であっても 敷地内空地に対する認識には差異が見られた。

\section{3 「花填」の物理的なイメーシ}

「花壇」の位置は、年齢・住宅形式を問わず、敷地内の建物と塀の間の 塀治い(424 名、38.8\%)、「マダン」の内部(306.名、28.0\%)、「庭」の内部 (194 名、17.8)\%)の順であった。この結果から、「花壇」は、「マダン」「庭」 に含まれる、敷地内の建物と塀の間の空地に、木と花などの植栽のため に設けられた空間として認識されていると考えられる。また、年齢、住宅 形式を問わず花壇」は狭いと認識している回答者が多かった。「花壇」の 高さについては、年齢・住宅形式を問わず、多くの人が「それほど高くな いと回答し、予備調查と異なる結果となった。以上より、「花增」の物理的 な空間構造については、植栽のために設けられた、狭く、低い空間として 認識されていることが分かった。

\section{4. 數地内空地のイメーシ}

本章では、予備調査で当該敷地内空地から感じられる」とされた単語 (伝統性、親しみ、こじんまり感、高級感、緑が多い、美しい、必要性)を用 い、どの程度そう感じるかを 5 段階 1 ; 非常にそうではない、2;ややそうで はない、3;普通、4;ややそうである、5;非常にそうである)で評価してもらつ た回答を考察する。本文中の( )の中の数字は、各項目の平均值である。
「伝統性」については、全体的に「庭(值；2.91)」より「マダン(值;3.93)」か ら伝統性を感じる回答者が多かった。特に $40,50 、 60$ 代以上など高年齢 ほど、そして現在韓屋住まいの人であるほど、「マダン」から伝統性を感じ ることが多かった。「親しみ」を見ると、「庭(值; 3.58)」より「マダン(値;4.09)」 から感じる人が多く、高年齡ほどその傾向は強かった。また、60 代以上の 人と現在韓屋住まいの人は「マダン」からも、「庭」からも親しみを感じ、「親 しみ」敷地内空地の経験有無に関連があることを示唆していると考えら れる。にじんまり感について見ると、「マダン(值; 3.65)」が「庭(值;3.38)」 より若干高く.60 代以上の人だけは「マダンかかこじんまりしていると感じ る回答者が多くあるのが分かった。高級感にについては、多くの人は「マ ダン(值；2.50)」より「庭(值; 3.52)」の方から高級感を感じると評価した。さら に、「マダン」から親しみ感した $40,50,60$ 代以上の人は逆に「庭」に高級 感をあまり感じないということも分かった。緑が多いににつては、「マダン (值;3.56)」より「庭(値; 4.05)」から緑が多いと感じる人が多く、年齢・住宅 形式別にあまり差がないことも分かった。「美しい」という項目では、「マタ ン(值; 3.40)」より「庭(值;4.05)」の方が美しいと感じる人が多く、特に 60 代 以上の人だけは「マダン」庭」もも美しさに高く評価したのが特徵的であっ た。「韓国住宅に必要であるという項目では「マダン(值；3.69)」が「庭(値； 3.29)」より若干高く、60 代以上の高齢者であるほど、現在韓屋と洋屋住ま いの人ほど、韓国住宅で敷地内空地が必要であると感じていることが分 かった。以上より、韓国人は「マダンからは伝統性、親しみ、こじんまり感 を感じ、「庭」からは高級感、緑が多い、美しさを感じることが分かった。特 に高齢者であるほど「マダンからの伝統性や必要性についてのイメージ を強く感しること、そして、若い人や集合住宅住まいの人は敷地内空地に 対する必要性を低く感じる傾向があった。

\section{5. 敷地内空地における生活行為}

本章では、予備調査で明らかになった教地内空地での生活行為から、 30 種類 (表-2 の生活行為面)を選択し、これらの生活行為に関する結果 について考察する。また、調査した生活行為の項目について、昔と今の 「マダン」庭」でどのように変化したか、「マダン」と庭」で行われる生活行 為の差異、さらに、これらの生活行為を年龄、居住歴別、住宅形式別に 分けて、考察する。

\section{1 昔と今の教地内空地ての生活行為の変化}

本節では、「マダン」庭」での昔と今の生活行為がどのように変化して きたかを把握するために、昔と今の住まいの中に「マダン」「庭」のある住 宅を対象にした。敷地内空地で行われる生活行為は当該空地の機能と 性格を規定しているため、この変化を考察することで、敷地内空地の昔と 今の機能や性格の変化を明確にすることができると考えられる。表-2 の 30 項目の生活行為を 7 つ一休憙・運動(休秝、遊び、運動)、会話関倸(平 林やベンチでの話、接待など)、趣味関係(植物や野菜の栽培、植物観賞 など)、家事関係(キムチ作りや物干しなど)、通行(駐車、通路)、洗面、非 日常生活(結婚式、町内会など)ーにグループ分けし、考察する。

表-5 から分かるように、「マダン」庭」のある住宅は昔に比べ $65.3 \%$ 、 $78.6 \%$ と減っていったが、敷地内空地で行われる生活行為は昔より、「マ ダン」では $73.4 \%$ 、「庭」では $83.6 \%$ と減っており、生活行為の減少比率 は敷地内空地の存在比率よりもつと大きいのが分かった。 
表-5. 敷地内空地の減少比率と総生活行為数の減少比率

\begin{tabular}{|c|c|c|c|c|c|r|}
\hline \multirow{2}{*}{} & \multicolumn{3}{|c|}{ マタyン } & \multicolumn{3}{|c|}{ 庭 } \\
\cline { 2 - 7 } & 昔 & 今 & 減少比率 & 昔 & 今 & 減少比率 \\
\hline 対象住宅数 & 923 & 320 & $65.3 \%$ & 557 & 148 & $78.6 \%$ \\
\hline 総生活行為数 & 10671 & 2287 & $73.4 \%$ & 5305 & 872 & $83.6 \%$ \\
\hline
\end{tabular}

図-4 は「マダン」「庭」での生活行為の内容を詳しくグラフで表したもの であるが、すべての生活行為について「タタン」庭」ともに昔の方が今より その数が多かった。そして、「マダン」の方が庭」より生活行為が多く行わ れており、「マダン」では家事関係の行為に、「庭」では趣味関係の行為に 集中していることが分かった。

次に、昔の「マダン」で行われる生活行為は家事関係 $\rightarrow$ 休憩・運動 $\rightarrow$ 趣味関係十会話関係の順であったが、今の「マダン」では、家事関係 $\rightarrow$ 趣味関係 $\rightarrow$ 休䕀・運動 $\rightarrow$ 会話関係であり、「マダン」は家事関係の生活 行為が行われる空間として説明できると考えられる(図-5 の上)。かつ、昔 の「庭」では、趣味関係 $\rightarrow$ 家事関係 $\rightarrow$ 休䕀・運動 $\rightarrow$ 会話関倸の順であっ たが、今の「庭」でもその順序は変わっていないことから「庭」は趣味関係 の行為が行われる空間之説明できる(図-5 の下)。特に「マダン」での家事 関係と通行行為、「庭」での趣味関係の生活行為は、総生活行為数から 見ると、昔より今の方が增加していることが分かった。

これらの結果から、「マダン」「庭」で行われる生活行為の数は昔より減 うているが、主に行われる生活行為として、「マダン」では家事関係の行 為、「庭」では趣味関係の生活行為が昔から今へと変わりなく継続してお り、敷地内空地の中で行われる主な生活行為として当該空地の機能や 役割を説明できると考えられる。

\section{2 「マダン」庭」での生活行為}

本節では、現在の住まいで「ダン」庭」があり、各空地で行われる今 の生活行為を対象に、年齢、居住歴、住宅形式別の特徵を明らかにする。 図一6は、生活行為を各属性別の人数で除して、表したグラフである。

年齢別の生活行為を見ると、「マダン」では家事関係の生活行為に、 「庭」では趣味関係の生活行為に集中しているのが分かった(図一 $6(\mathrm{~A}))$ 。 た、各生活行為について年齢別の著しい差異は見られないことから、3、4 章で語うた敷地内空地の存在性や、必要性など敷地内空地から感じら れる様々なイメージについての評価が低かった若い世代の回答者も、実 際の生活行為は高龄層の回答者と比べ少なくないことを示唆していると 考えられる。

居住歴別の生活行為については、「マダン」では家事関係、「庭」では 趣味関係に集中しており、居住歴の長さ別に偏りなく、大きな差異は見ら れなかった(図-6(B))。

住宅形式別の生活行為については、「マダン」では家事関係、「庭」で は趣味関係に集中しているが、住宅形式別に行われる生活行為に大き な差異は見られなかったが、韓屋住まいの回答者が「マダン」での生活行 為に他の住宅形式より若干多く回答しているのが分かった(図-6(C))。

これらの結果から、「マダンでは家事、「庭」では趣味関保の生活行為 に回答者や住居の属性を問わず集中しており、主に行われる生活行為と して規定できる。そして、各生活行為に对して、その行為を構成する各々 の属性別には差がなく等しく分布していることが分かった。

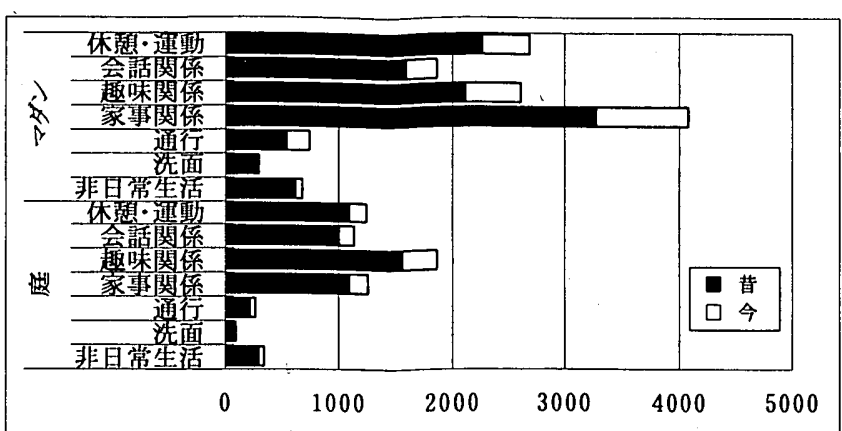

図-4. 敷地内空地で行われる生活行為の昔と今の変化

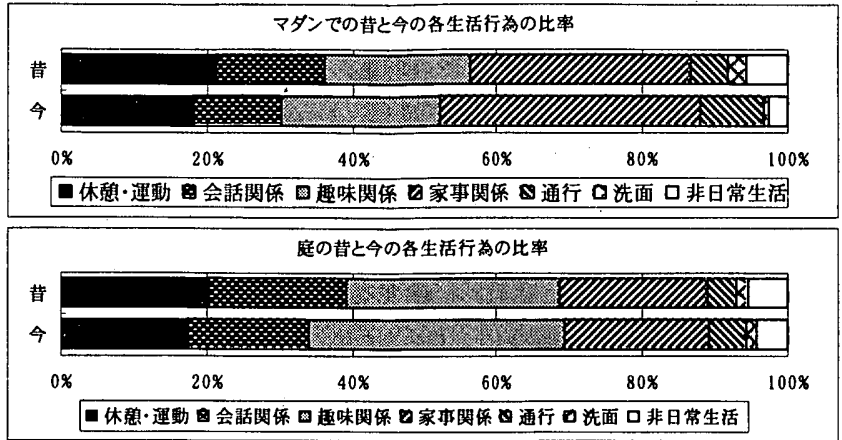

図-5. 各生活行為の昔と今の比率変化

(A)

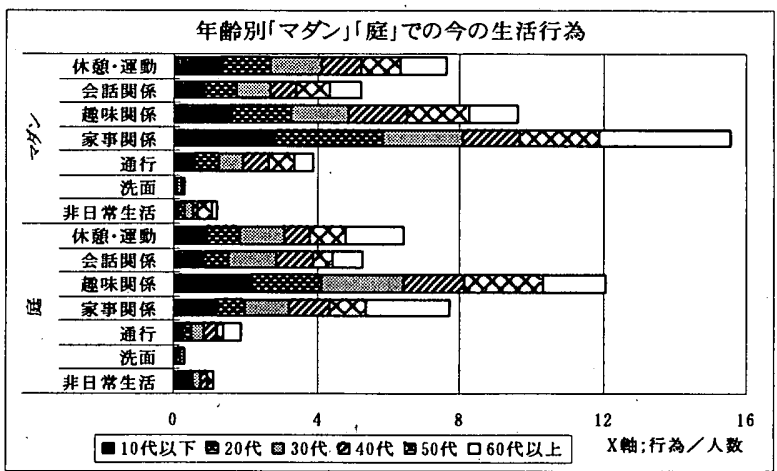

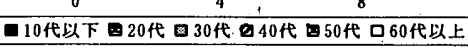

\section{6}

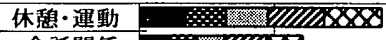

会話関係 $\%$

i 趣味関係 泟

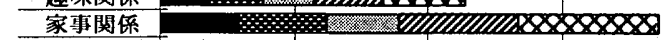

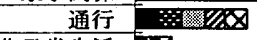

(B) 非日常生活

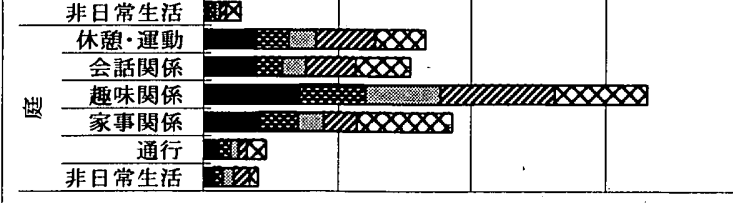
非日常生活 政

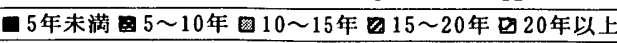
住宅形式別「マダン」庭での今の生活行為

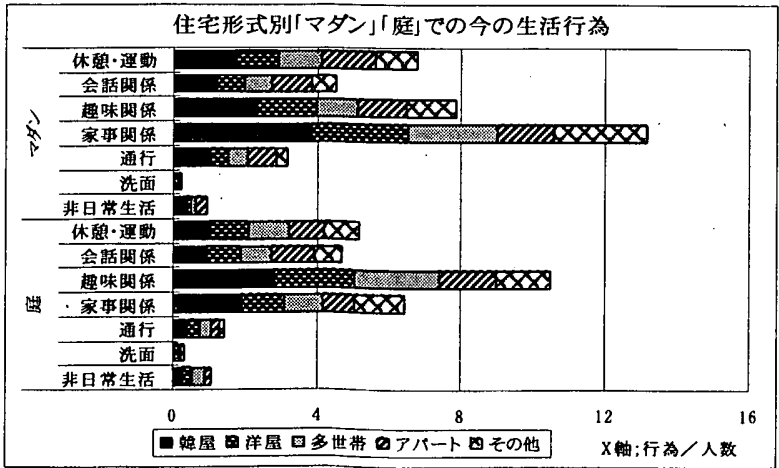

図-6. 年齢·居住歴·住宅形式別「ダン」と庭」での生活行為 


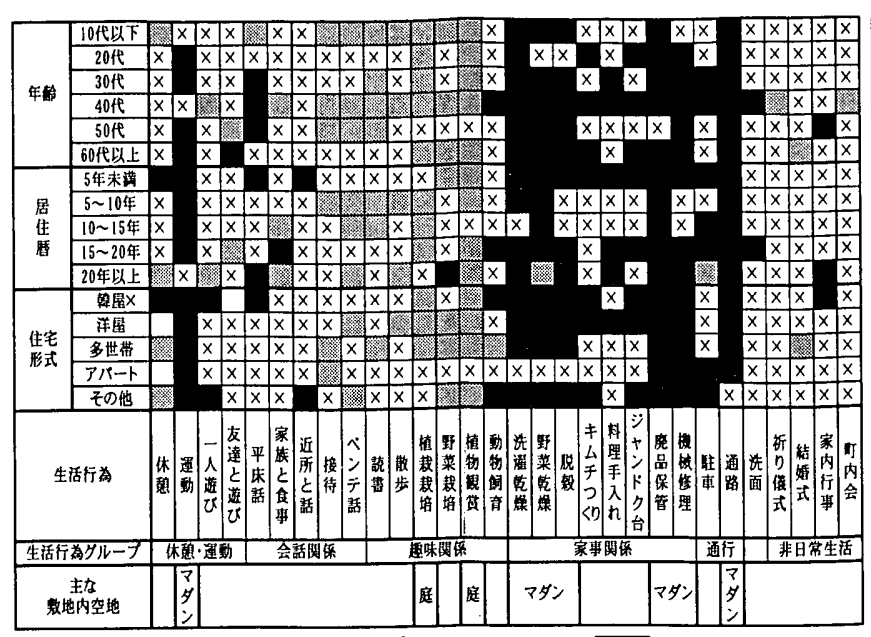

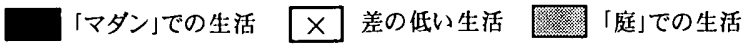

図-7。年㱓別、性別、住宅形式別、居住歴別 敷地内空地で行われている生活行為

図-7 は、回答者の属性別に明確ではなかった生 活行為の差異を詳しく見るために、「マダン」庭」で行 われる生活行為の差が $10 \%$ 以上である行為がどの 空地で行われるかを明らかにするために作った図で ある。全体的に「マダン」で行われる生活行為の方が 「庭」より種類、量ともに多かった。また，運動、家事の 一部分、通路は主に「マダン」で行われる生活行為と して、植栽栽培や植物観賞は「庭」で行われる生活行 為として位置づけることができた。そして、40 代、60 代 以上、居住歴が 5 年末満、 $15 \sim 20$ 年、現在の住まい が韓屋の回答者は他の属性の回答者に比べ、庭」よ りも「マダン」を多く使用していることが分かった。

5.3 アパート住まいの人の敷地内空地で生活 行為

韓国における代表的な集合住宅である 5 階以上の アパート住まいの回答者のうち、敷地の中に「マダン」 「庭」があると回答した人を対象に敷地内空地での生 活行為について考察した。調查対象者 1,195 名の内 アパート住まいの人は 644 名であり、その中で「マダ ン」があると回答した人は $9.8 \%$ の 62 名、「庭」があると 回答した人は $6.5 \%$ の 42 名で少なかった。しかし、 $10 \%$ 程度のアパート住まいの人であっても、大勢の人 と一緒に使う空地を「マダン」「庭」して使っている事 実は無視できず重要であると考えられる。

「マダン」がある人のそこでの生活行為を見ると、 駐車が最も多く、次いで廃品保管、運動、休唕の 順になった。また「庭」がある人のそこでの生活行 為は植栽と植物の観賞など緑に関係する行為、べ ンチでの話、休覟の順であった(図-8)。

\section{6. 写真の呼び名について}

本章は、韓国人のイメージの中の敷地内空地が実際の空間でどのよう な㭔称で呼ばれるかを、写真を用いて調查し、考察した。アンケート調査

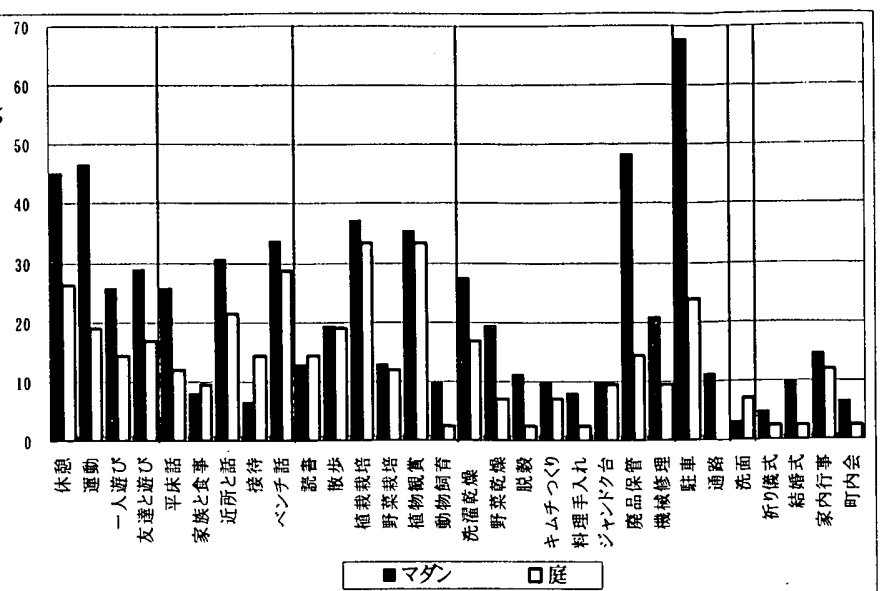

図-8： 5 階以上のアパート住まい人の敖地内空地での生活行為

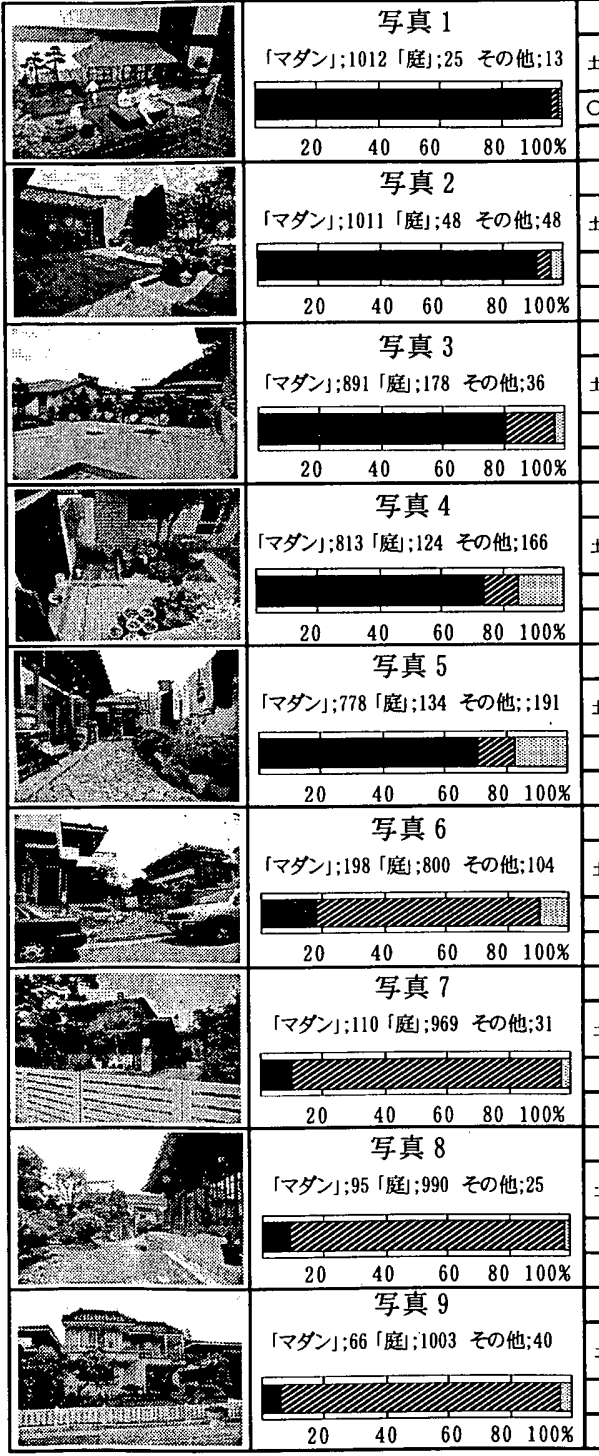

\begin{tabular}{|c|c|c|c|c|c|c|c|c|c|}
\hline \multicolumn{3}{|c|}{ 来の材算 } & \multicolumn{7}{|c|}{ 圈いているもの } \\
\hline \multirow[t]{2}{*}{ 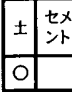 } & $\begin{array}{l}31 \\
\mu 1\end{array}$ & 芝生 & $\begin{array}{l}\text { 氷道 } \\
\text { (井) }\end{array}$ & 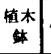 & 低木高木 & 平沫 & $\begin{array}{ll}\cdots \\
q\end{array}$ & \multirow{2}{*}{\multicolumn{2}{|c|}{\begin{tabular}{l|l} 
& 告 \\
& 0 \\
\end{tabular}}} \\
\hline & & & 0 & & 0 & 0 & & & \\
\hline \multicolumn{10}{|c|}{ 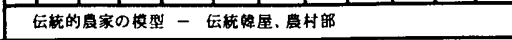 } \\
\hline \multicolumn{3}{|c|}{ 米の材要 } & \multicolumn{7}{|c|}{ 苗いているもの } \\
\hline 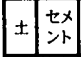 & $\begin{array}{l}\text { 多 } \\
\text { un }\end{array}$ & 之生 & $\begin{array}{c}\text { 水道 } \\
(4 \#)\end{array}$ & \begin{tabular}{|l|} 
梅杰 \\
\\
\end{tabular} & 低末商木 & 平因 & \begin{tabular}{|l|}
$\ddot{y}$ \\
\hdashline
\end{tabular} & 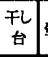 & 重台 \\
\hline & o & & 0 & 0 & 0 & & & 0 & 0 \\
\hline \multicolumn{10}{|c|}{ 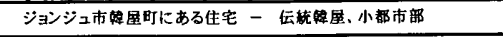 } \\
\hline \multicolumn{3}{|c|}{ 束の材粠 } & \multicolumn{7}{|c|}{ 凬いているもの } \\
\hline \pm 祝 & $\begin{array}{l}31 \\
11\end{array}$ & 芝生 & \begin{tabular}{|l|l}
$\begin{array}{c}\text { 水 } \\
\text { (\#) }\end{array}$ \\
\end{tabular} & \begin{tabular}{|l|} 
植木 \\
妹
\end{tabular} & 低木高入 & 平因 & 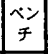 & 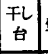 & 重古 \\
\hline 0 & & & 0 & 0 & & & & 0 & 0 \\
\hline \multicolumn{10}{|c|}{ 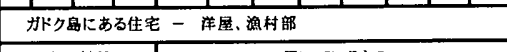 } \\
\hline \multicolumn{3}{|c|}{ 東の材贯 } & \multicolumn{7}{|c|}{ 㧽いているもの } \\
\hline 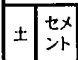 & $\begin{array}{l}31 \\
\mathrm{u}\end{array}$ & 芝生 & \begin{tabular}{|c|} 
水道 \\
$(\mathrm{A})$
\end{tabular} & \begin{tabular}{|c|} 
植木 \\
4
\end{tabular} & 但末高大 & 平㳻 & $\begin{array}{l}\text { ベン } \\
\text { ₹ }\end{array}$ & \begin{tabular}{|c|}
$\mathrm{Fl}$ \\
$\mathrm{\theta}$
\end{tabular} & 需台 \\
\hline & 0 & & $\mathrm{O}$ & 0 & $\overline{0}$ & & & 0 & \\
\hline \multicolumn{10}{|c|}{ ヨ七市にあるる住宅一样㢆，小都市的 } \\
\hline \multicolumn{3}{|c|}{ 来の材算 } & \multicolumn{7}{|c|}{ 凮いているもの } \\
\hline$\pm\left[\begin{array}{l}\text { tex } \\
\end{array}\right.$ & $\begin{array}{l}91 \\
\mu 1\end{array}$ & 艺生 & \begin{tabular}{|l|} 
水道 \\
(开)
\end{tabular} & 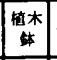 & 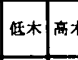 & 平困 & $\begin{array}{c}92 \\
\mp \\
\end{array}$ & \begin{tabular}{|c|} 
干l \\
台 \\
\end{tabular} & 典台 \\
\hline \pm & 0 & & & & 0 & & & 0 & \\
\hline \multicolumn{10}{|c|}{ 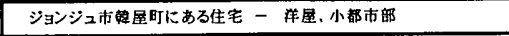 } \\
\hline \multicolumn{3}{|c|}{ 来の标笛 } & \multicolumn{7}{|c|}{ 通いているもの } \\
\hline 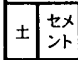 & $\mid \begin{array}{l}11 \\
11\end{array}$ & 艺生 & 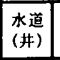 & 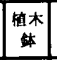 & \begin{tabular}{|l|l|} 
低水高 \\
\end{tabular} & 平泷 & 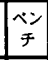 & \begin{tabular}{|c|} 
舟 \\
\end{tabular} & 重台 \\
\hline & & 0 & 0 & & \begin{tabular}{|l|l|l|}
0 & 0 \\
\end{tabular} & & & 0 & \\
\hline \multicolumn{10}{|c|}{ 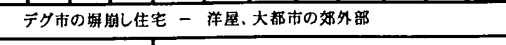 } \\
\hline \multicolumn{3}{|c|}{ 来の材婴 } & \multicolumn{7}{|c|}{ 豢いているもの } \\
\hline 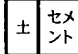 & $\begin{array}{l}31 \\
\mu\end{array}$ & 芝生 & 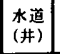 & 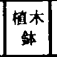 & \begin{tabular}{|l|l} 
低水高 \\
\end{tabular} & 平床 & 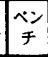 & \begin{tabular}{|c|}
$\mp 2$ \\
$b$ \\
\end{tabular} & 重台 \\
\hline & & 0 & & & \begin{tabular}{l|l}
0 & 0 \\
\end{tabular} & & 0 & & \\
\hline 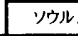 & 倜辺。 & 力建慜 & 家か設期 & 㰻た住 & 住宅 - & 姩座、大 & 都市。 & 㜢外豆 & \\
\hline & の材贯 & & & & 霜以下 & いるもの & & & \\
\hline 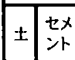 & 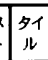 & 芝生 & 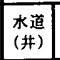 & 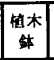 & 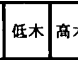 & 木平林 & 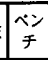 & \begin{tabular}{|c|}
$\begin{array}{c}F L \\
t\end{array}$ \\
\end{tabular} & 鱼台 \\
\hline & & 0 & & 0 & \begin{tabular}{|l|l|l|}
0 & 0 \\
\end{tabular} & & & & \\
\hline ショョン & 泛菏 & 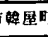 & ऍたある & 住宅 & 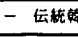 & 䇈、小表 & 揢市暗 & & \\
\hline & の材望 & & & & 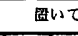 & 6らるもの & & & \\
\hline$\pm\left.\right|_{2 x} ^{\text {保 }}$ & 多1 & 芝生 & \begin{tabular}{|l|} 
皮道 \\
(并)
\end{tabular} & 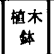 & 低水高了 & 太平来 & 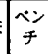 & 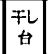 & 重台 \\
\hline & & 0 & & & $\mathrm{O}$ & & 0 & & \\
\hline
\end{tabular}

図-9．写真の呼称と地面の材質·置物

マダン

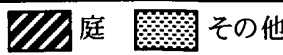

に用いられた 9 枚の写真は、韓国住宅の形式一伝統韓屋、洋屋一、そし て、地域一農村部、都市部、郊外部一などの基準で選んだものである。9 枚の写真の呼称しして、「マダン」庭」、「その他」を選んでもらい、選んだ 回答をグラフ化した(図-9)。さらに、図-9 の右側に空地の写真の地面の 
材質や置かれているものを分類した。

写真 1〜5の呼称は「マダン」、写真 6〜9の呼称は「庭」となり、明確に分 類された。地面の材質を見ると、「マダン」と回答された写真には土、セメ ント、タイルが、「庭」と回答された写真はすべて芝生になっていた。さらに、 置物を見ると、呼称が「マダン」である写真では洗濯物干し台やジャンドク 台など植物以外のものが多く置かれていたが、呼称が「庭」である写真で は植物やベンチが置かれていた。また、植物に関してみると、呼称が「マ ダン」の写真では、植木鉢や高木が植えられており、植木錰は動かすこと ができ、高木の下では人の活動が可能であるので、「マダン」におけるこ れらの植物は人々の生活行為に制約を加えないものと考えられる。

このように、呼称が「マダン」である空間と、呼称が「庭」である空間の間 には、地面の材質、置かれているものの面で比較的明確な差異が認めら れたが、呼称が「ダン」である写真 $3 〜 5$ は「庭」と答えた回答者、そして、 呼称が庭」であった写真 6 は、「マダン」と答えた回答者も $20 \%$ 以上見ら れることから、視覚的な面で「ダン」か「庭」か明確ではない要素が入っ ていると考えられる。「ダン」呼ばれた写真 3〜5にはよく整理された植 木鉢、盆栽、花壇などが目立ち、「庭」と呼ばれた写真 6 には道路治いに 自動車が見られ、空地の奥には布団が干されているなど、敷地内空地の 呼称と地面の材質や置物などの要素にはある関係性が存在すると考えら れる。

\section{7. まとめ}

本研究では、韓国住宅の敷地内空地である「マダン」庭」などについて、 韓国人の認識の中の敷地内空地に対する物理的な面、イメージ的な面、 敷地内空地で行われる生活行為の面、そして呼称の点から調査し、考察 を行った。全体的に「マダン」「庭」に対する認識は年踰別に、住宅形式別 に差異があり、場地内空地での昔と今の生活行為、そして「ダン」と庭」 の主な生活行為に差があることが分かった。具体的な内容は以下のよう にまとめられる。

(1)，韓国人の認識の中の物理的な面を見ると、「韓国住宅に必ず存在す るの項目では、高齢者であるほど、現在の住宅形式が韓屋・洋屋である ほど「マダン」は「韓国住宅に必ずある空間」として認識して傾向があり、 「庭」「花壇」については年齢・住宅形式を問わず「そうではないと認識して いる回答者が多かった。そして、年龄や住宅形式別に「マダン」庭」につい ての大きさ、広さ、門鎖性についての認識に差異が見られた。

(2) 「「マダン」庭にについてのイメージの面を見ると、「マダン」からは「伝 統性」「親しみ」にじんまり感」必要性」を感じ、高跉者と韓屋住まいの回 答者でその傾向が強かった。そして、「庭」からは「高級感」「緑の多さ」美 しさ」必要性」を感じるが、年龄と住宅形式別の差はないのが特徵的であ った。「マダン」から感じられる内容に高踰者と韓屋住まいの回答者が特 性のある傾向を見せる事から、当該敷地内空地の経験の有無と感じられ るイメージには深い関係があることを示していると考えられる。

(3)「マダン」庭」のある住宅は、昔に比べ大幅に減少しており、空地中 での生活行為の総数はさらに大きな比率で減少しているのが明らかにな った。そして、「マダン」庭」での生活行為を比べると、「マダン」の方は 「庭」の 2 倍程度の生活行為の数が見られ、韓国人は「庭」より「マダン」で
多くの生活行為を行うことが分かった。敭地内空地で行われる主な生活 は当該空地の機能や性格を説明する点で見ると、「マダン」では家事関 係の生活行為、「庭」では趣味関係の生活行為が昔から今へと変わりなく 続けられているのが明らかになった。かつ、まとめの(2)で述へた敷地内 空地に対するイメージの評価は各属性別に異なつていたが、実際の敷地 内空地での生活行為は属性別に偏りなく行っているのが分かった。

（4）実際の敖地内空地の写真を用い、その空間の呼称を調查、考察し たところ、「マダン」と呼ばれた敷地内空地の要素としては、土、セメント、 タイルの地面、物干し台や水道など作業のためのものが置かれている空 間、植木鉢や盆栽、低木などの緑が挙げられていた。そして、「庭」と呼ば れた敖地内空地には、芝生の地面、高木や低木が植えられていた。敷地 内空地の外見(特に、地面の材質、置かれているもの)とその空間の呼称 は深い関係があることを明確にした上で、敖地内空地のあり方を計画すべ きであると考えられる。

本研究では、「マダン」「庭」「花壇」の韓国住宅の敷地内空地について 韓国人がどう認識しているかを明らかにしたが、今後の課題として、実際 の韓国住宅における敷地内空地の使い方について調查を行い、さらに 詳紐に数地内空地の役割と機能を明確にする必要があると考えられる。

【補注】

(1)「マタンノという空間は韓国固有の住宅にある敖地内空地である。

(2)「庭園(㐸全)」は、日本語の「庭」に該当する韓国語の単語である。以下の本文 では庭」という言葉で表記する。

(3) 本研究で曹かれている「物理的な面」は、韓国住宅の配犆図、入り口、幈の位 㯰の示す図をデータとして分析したものではなく、敖地内空地の大きさや、地面の 材質などその形を理解できる項目についての表現である。

(4) 本研究では、韓国住宅の敬地内空地の一つとして、「マダン」「庭しははその役割 や機能が異なる花境」も調査対象に入れて調查を行い、考察をした。

(5) アンケート調查に用いられた敖地内空地の写真は、敖地内空地の構成要素を、 CG などを用い段階的に表現したものではないが、地域や住宅形式の多様性を重 視して選んだものである。

（6）生活行為の面で花埪をを対象から除外したのは、図-1の政地内空地について の説明の中で、「花境」で行われた生活行為は数や内容の面で非常に少なかった ためである。

（7）韓屋は、西洋式建物に対し、韓国固有の建築様式で建てた建物を指す。

（8）洋屋は、植民地時代から現れた住宅で、西洋式で建てた建物を指す。

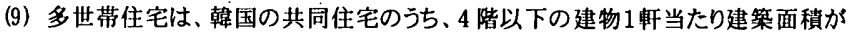
660 m²下の住宅を指す。

(10）韓国の中でアパートは、5階以上の共同住宅を指す。

(11) その他の住宅形式には、ビラ、社宅などがある。

（12）本論文の中で、韓国住宅の中に各種の敖地内空地があるかないかを「存在 性」と呼ぶ。

\section{【参考文献】}

1）金奉暗、小浦久子(2003 年)、敷き際の開放によるマタタンの変容と生活空間に 及ほす効果に関する研究、平成 14 年度都市計画論文集日本都市計画学会、 11 月、p.1117 1122

2) ハングル学会、われわれ言葉大きい辞書(1992 年)、語文閣

3）ベク・ヘソン、朴・ヨンギ(2002 年)、共同住宅団地内屋外生活空間に対する居 住者意識調查书よび利用行熊分析研究、大韓建築学会論文集計画系 18 巻 12 号、 p. $91 \sim 97$

4) 曹卓植(1996 年)、「マダン」の語意と超越的な特性に関する研究、大韓建築学 会論文集計画系 12 巻 2 号、 p. $91 \sim 97$

5) 金成柱、金銿仁(1996 年)、「マダン」の利用と変容、大韓建築学会学術発表論 文集 16 巻 1 号, pp.53 56

6) 李賢㛒（1994 年）、晖国の「日式住宅に見る住文化の持続と変容一日本の長屋 との比較文化的考察-、東京大学大学院工学系研究科愽士学位論文

7) 全現美(2001 作)、韓国都市の住居集合睘境における屋外空間の满成之評価 に関する研究、大阪大学大学院工学研究科博士学位論文

8) 川喜田二郎(1970 年)、続:発想法、中公新書 